\title{
Protective capacity of mangroves during tropical storms: a case study from 'Wilma' and 'Gamma' in Belize
}

\author{
Elise F. Granek ${ }^{1,3, *}$, Benjamin I. Ruttenberg ${ }^{2}$ \\ ${ }^{1}$ Department of Zoology, Oregon State University, Corvallis, Oregon 97330, USA \\ ${ }^{2}$ Department of Ecology, Evolution and Marine Biology, University of California, Santa Barbara, California 93106, USA \\ ${ }^{3}$ Present address: Environmental Sciences and Resources, Portland State University, Portland, Oregon 97207, USA
}

\begin{abstract}
Globally threatened mangrove forest habitat is often considered an important buffer protecting coastlines from wave and storm impacts and coastal erosion. However, there is little empirical data quantifying the protective effects of mangroves during storms, primarily because of the difficulty of predicting where and when a storm will intersect the shoreline, to facilitate data collection before and after storm events. In 2005, opportunistic results from an ongoing study quantifying differences between intact and cleared mangrove areas on Turneffe Atoll, Belize, provided such pre- and post-storm data from tropical storms 'Wilma' (later a Category 5 Hurricane) and 'Gamma'. We compared differences in equipment retention rates of 3 types of experimental devices previously installed in adjacent intact and cleared mangrove areas. Retention rates were greater in intact mangrove areas, empirically demonstrating the protective capacity of mangroves during moderate magnitude storm events. The results support the assumption that removal of mangroves diminishes coastal protection not only during catastrophic storm events such as hurricanes or tsunamis, but also during less energetic but more frequent events, such as tropical storms. This highlights the importance of improved coastal zone management, as storm events may increase in frequency and intensity with changing climate, and coastal mangrove forest habitats continue to decline in size and number.
\end{abstract}

KEY WORDS: Climate change - Coastal buffer $\cdot$ Deforestation $\cdot$ Ecosystem service $\cdot$ Hurricane Tsunami

\section{INTRODUCTION}

Significant mangrove deforestation has removed much of the vegetative buffer that once lined tropical and subtropical coastlines. Today, less than $65 \%$ of the historic mangrove cover exists along these coasts; globally, $30 \%$ of mangrove habitat has been lost over the last 50 yr (Field et al. 1998, Alongi 2002, Williams 2005). This habitat conversion provides land for shrimp farms, agriculture, towns, and resorts, but there may be significant costs resulting from this mangrove deforestation, including loss of ecosystem services such as nursery habitats, filtration of runoff, and coastal protection (e.g. Mazda et al. 2002, Mumby et al. 2004). The role of man- groves as protective buffers against storm events has been widely discussed (Ogden \& Gladfelter 1983, UNEP 1995, Cesar 1996, Mazda et al. 1997a, Field et al. 1998, Moberg and Folke 1999, Alongi 2002, Wells et al. 2006); however, until recently, few studies have collected quantitative evidence to demonstrate this role.

The December 26, 2004, catastrophic tsunami in the Indian Ocean provided the first example of a storm event for which researchers were able to extensively and quantitatively examine mangroves as coastal buffers. Dahdouh-Guebas et al. (2005) and Danielson et al. (2005) reported that intact mangroves along coastlines were successful barriers to strong wave action, and reduced coastal and property damage compared 
with adjacent cleared mangrove areas. Loss of human life was also reduced near intact mangroves (Kar \& Kar 2005). Despite these findings, there are few data on the role mangroves play in buffering coastlines during smaller, but more frequent, storm events (e.g. tropical storms) and the level of protection provided at the seaward edge of the stand. Demonstrating that mangroves provide this valuable ecosystem service during less energetic events is critical in the face of the continuing global decline of mangrove cover due to anthropogenic disturbance.

Because it is difficult to predict where and when a storm will make landfall and therefore difficult to collect pre- and poststorm data, there is limited evidence of the protective capacity of mangroves during storm events. In Belize, we had initiated an experiment evaluating a variety of ecological differences between intact and anthropogenically cleared mangrove areas. Our study site was hit by tropical storms 'Wilma' and 'Gamma' in October and November 2005, providing the rare opportunity to quantify differences in coastal protection.

\section{MATERIALS AND METHODS}

The study was designed to evaluate the impact of clearing mangroves on community and ecosystem properties of mangrove habitats and adjacent coral reefs; 7 paired study sites were arrayed along a $30 \mathrm{~km}$ stretch of coastline of Turneffe Atoll, Belize (Fig. 1). Each site consisted of one area of intact and one area of cleared mangroves. These sites met the following criteria: (1) a minimum of $75 \mathrm{~m}$ stretch of cleared coastline adjacent to a stretch of at least $100 \mathrm{~m}$ of intact red mangroves Rhizophora mangle L.; (2) fringing or patch reefs within $200 \mathrm{~m}$ of the seaward mangrove edge; (3) location at least $10 \mathrm{~km}$ from major human development to exclude potential sources of anthropogenic nutrients; and (4) similar exposure to wave action in the cleared and intact areas. All sites were characterized by $R$. mangle trees, except where stands had been

removed for agriculture, construction or viewsheds. The atoll is surrounded by a barrier reef with reef patches at depths of 1 to $3 \mathrm{~m}$ along the flats. At all sites, water depth varied between 0.75 to $1.25 \mathrm{~m}$ through a $\sim 0.5 \mathrm{~m}$ tidal range. Cleared areas ranged from 75 to $250 \mathrm{~m}$ in length along-shore, and were either recent (within 12 mo of study deployment) or historic ( 15 yr prior). Recently cleared sites had some remaining 3dimensional subtidal prop root structure; historically cleared sites were devoid of root structure above the substrate. Intact mangrove habitat was fringe forest with a canopy height of 4 to $5 \mathrm{~m}$ and was composed of $R$. mangle exclusively at the seaward edge.

Three different types of experiments were in progress when the storms hit. Each experiment utilized replicate treatments deployed along a $20 \mathrm{~m}$ transect line parallel to shore. At each intact mangrove study area, transects were placed within the mangrove prop roots of the most seaward tree; in the cleared sites, transect lines were deployed where the roots were once present. Each experimental transect line had 3 sediment traps and 2 pairs of herbivore exclusion cages and cage controls (Fig. 2). A subset of the sites

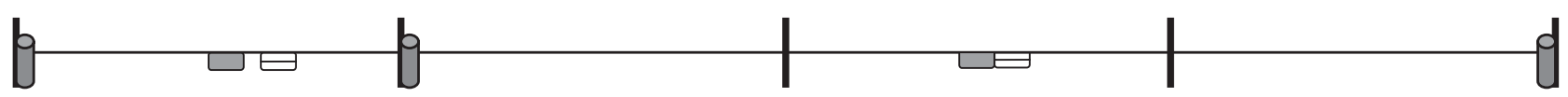

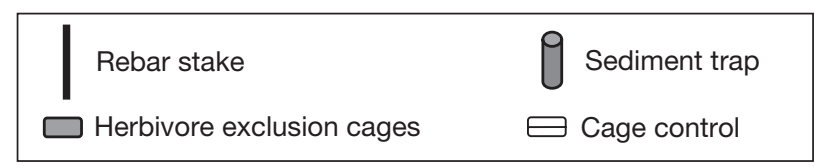

Fig. 2. Equipment deployed along a $20 \mathrm{~m}$ transect line parallel to the shore at each cleared and intact mangrove forest site 
also had shades, designed to test the effects of light on algal growth, and shade controls. Installation of experimental devices was similar in all areas.

Herbivore exclusion cages were mesh bags held open with PVC rings and cinched down with cable ties. Cages and cage controls were strung on a line $\sim 1 \mathrm{~m}$ above the substrate and 0.25 to $0.5 \mathrm{~m}$ below the water surface; the line was attached at either end to rebar stakes. Sediment traps were PVC tubes capped at the bottom and anchored to rebar stakes with cable ties; we deployed 3 sediment traps at each site. Shades were PVC quadrats covered with mesh; shade controls lacked mesh covers. The shades were cinched to four $1 \mathrm{~m}$ tall steel rebar stakes (at each corner of the quadrat). All rebar stakes were $1 \mathrm{~m} \times 1.3 \mathrm{~cm}$ and were anchored $\sim 0.4 \mathrm{~m}$ below the substrate surface; there was one shade and one shade control per site, adjacent to the transect.

The experiments were initiated in July 2005. At the end of September 2005, all field equipment was monitored and was intact. Three weeks later (October 18), 'Wilma' moved past Turneffe Atoll with tropical storm-force winds, waves and surge (Pasch et al. 2006). Three weeks after 'Wilma' passed, 'Gamma' stalled offshore of Belize for 2.5 d (November 16 to 18), battering Turneffe Atoll with high winds, surge and flooding rains (Stewart 2005). Based on the Saffir-Simpson scale, these 2 tropical storm-force events were characterized by sustained wind speeds ranging from 40 to 73 knots with peak gusts up to 81 knots and surge up to $1.5 \mathrm{~m}$. There is no weather station at Turneffe Atoll, so wind and surge maxima data for the atoll are not available.

We returned to the field in January 2006 and measured the impact of these 2 tropical storms on the loss rates of experimental equipment. The difference in the loss of deployed field equipment between mangroveintact and mangrove-cleared areas provided an unplanned, quantitative measure of the protective capacity of the mangroves at the seaward edge of the stand. Because the experiments were designed to detect differences in a number of ecological responses between cleared and intact areas, we do not have data on stand structure characteristics in the intact areas. However, our interest in the effects of shading did lead us to collect light intensity data in both cleared and intact areas using a LiCor light meter with an underwater sensor before the tropical storms hit. Not surprisingly, light intensity was more than an order of magnitude higher in the cleared areas. Differences in light penetration among intact areas have been used as a proxy for stand density and stand structure in a number of forest types (e.g. Hale 2003, Takashima et al. 2006 and references therein), which allows us to examine the effects of stand structure on the loss rate of experimental equipment in the intact areas.
We recorded the percent of each type of equipment retained at each site, and used an arcsin square root transformation for all data (Sokal \& Rolf 1995).

\section{RESULTS}

The percentage of herbivore exclusion cages and cage controls lost during the storms was more than 6fold higher in the cleared areas compared to the intact mangrove areas (paired $t$-test; $t=7.78$, df $=6, \mathrm{p}=$ 0.0002) (Fig. 3). Sediment traps were also lost at a significantly higher rate in the cleared areas than the intact areas (paired $t$-test; $t=4.60, \mathrm{df}=6, \mathrm{p}=0.0037$ ) (Fig. 3). Shades were only deployed at a subset of the sites $(\mathrm{n}=4)$, reducing the power to detect differences in loss rates between treatments. Still, shades were lost at a higher rate in the cleared versus intact areas, but these differences were only marginally significant (paired $t$-test; $t=2.61, \mathrm{df}=3, \mathrm{p}=0.079$ ) (Fig. 3).

There was little variation in light penetration within intact areas (2 to $7.5 \%$ ) and survivorship of equipment (i.e. most equipment survived well in intact areas).

\section{DISCUSSION}

The appearance of 2 consecutive tropical storm events during an ongoing experimental investigation of differences between intact and cleared mangrove areas afforded a rare opportunity to evaluate the role of mangroves in attenuating the impacts of major storms. Our equipment survived significantly better in areas with intact mangroves (Fig. 3), demonstrating that mangroves provide substantial coastal protection

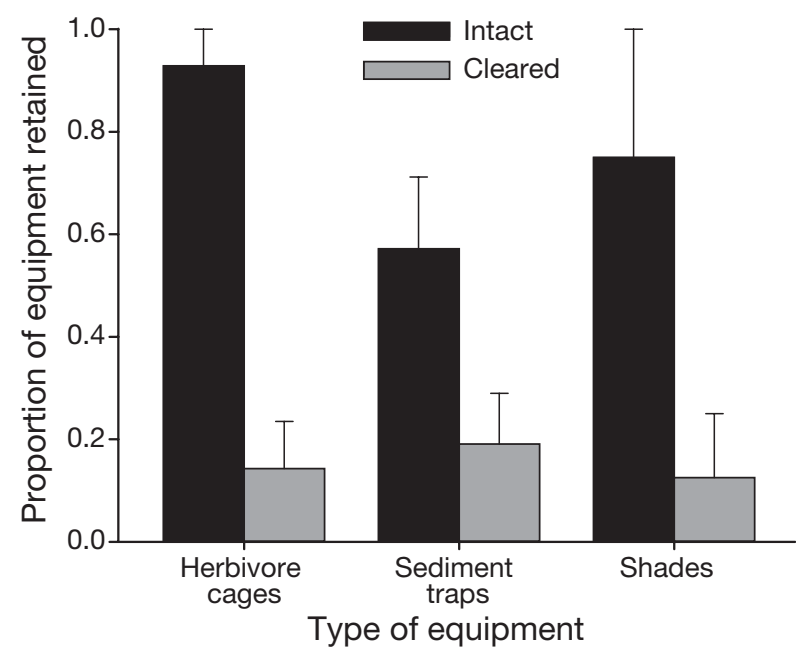

Fig. 3. Percent retention (mean + SE) of 3 types of field equipment during tropical storms 'Wilma' and 'Gamma' in intact versus adjacent cleared mangrove areas 
from tropical storms relative to areas that have been cleared. These data are consistent with the hypothesis that intact mangroves, like other coastal vegetation, diminish wave and surge impacts associated with not only large storm events such as hurricanes, but also smaller, more frequent tropical storms (Mazda et al. 1997a, Feagin et al. 2005, Williams 2005).

In many cases, it was unclear which mechanism caused loss of equipment. Storms may change or weaken sediments, making it more likely that the anchoring stakes and any associated equipment would be pulled out. Drag forces may also pull equipment directly off the anchoring stakes. Whatever the mechanism, mangroves should help stabilize sediments (e.g. Cahoon et al. 2003) and attenuate drag due to wave action (e.g. Mazda et al. 1997b), both of which should lead to greater retention of equipment in areas with intact mangroves, as we observed.

Not surprisingly, storm size was important in determining impact. All field equipment remained in place from July to September, despite numerous smaller thunderstorms and the localized winds and surge that resulted from them. No loss of field equipment occurred until 'Wilma' and 'Gamma' traversed Turneffe Atoll. When these traversed the atoll, they were 'only' tropical storms, with sustained winds of up to $\sim 70$ knots and storm surge of $\sim 1.5 \mathrm{~m}$. Hurricane-force storms tend to attract more attention in the media (and from policymakers), but tropical storms are much more frequent (Avila et al. 2000). Results from this study provide the first quantitative evidence that mangroves can provide coastal protection from these less intense but more frequent storms, in addition to the protection they may provide from major events such as tsunamis (Dahdouh-Guebas et al. 2005, Danielson et al. 2005). Our equipment survived these storms at significantly higher rates behind a single layer of live mangrove root structure compared to similar areas with no remaining live root structure.

When we examined the relationship between light intensity (as a proxy for stand structure; recognizing that light penetration should decrease in stands with more canopy closure, more branches, and higher structural development; e.g. Hale 2003, Takashima et al. 2006) and survivorship of equipment, we found a negative, but non-significant, relationship. A negative relationship suggests that increasing stand density, quantified in this case by the inverse of light penetration, may further mediate the degree of coastal protection that mangroves confer. We had no direct data on actual stand structure or the specific characteristics of the storms (precise direction, wind and wave intensity, etc.) that could have helped further elucidate the factors that influence the degree of protection afforded by mangroves.
Though these local site-level impacts are not easily scaled to coast-wide extents, the results presented here indicate that areas with intact mangroves react differently than disturbed areas during storm events (Dahdouh-Guebas et al. 2005, Danielson et al. 2005). It is difficult to determine how well survivorship of field equipment correlates with other measures of coastal impact, such as rates of erosion or beach loss. While no quantitative data exist in our study system, anecdotal evidence suggests that coastal erosion during 'Wilma' was much greater in areas where mangroves were cleared many years ago (E. Granek pers. obs., Fig. 4). It is also likely that the protective capacity of mangroves vary from one storm event and location to the next, and depends on the extent of storm damage to mangroves (Stoddart 1963, Doyle et al. 1995). Information on differences in flow velocities and tidal intrusion during storm events would provide further data on mangrove buffering during these high wave action and surge events. Future studies comparing differences in coastal erosion and sand or sediment transport between intact and cleared mangrove areas would contribute to our understanding of how these storm events are affecting coastlines over time (e.g. Mazda et al. 2002).

Information on the differences in tropical storm impacts between areas with and without intact mangroves highlights the importance of mangrove conservation and restoration strategies (Field et al. 1998, Ellison 2000, Check 2005). Corresponding empirical evidence quantifying this role for coral reefs across a range of storm magnitudes is likewise needed. As the frequency and intensity of major storm events is likely to rise in conjunction with climate change (McCarthy et al. 2001), understanding the capacity of mangroves and coral reefs to buffer shorelines is increasingly relevant. Similar to other coastal vegetation types (Feagin

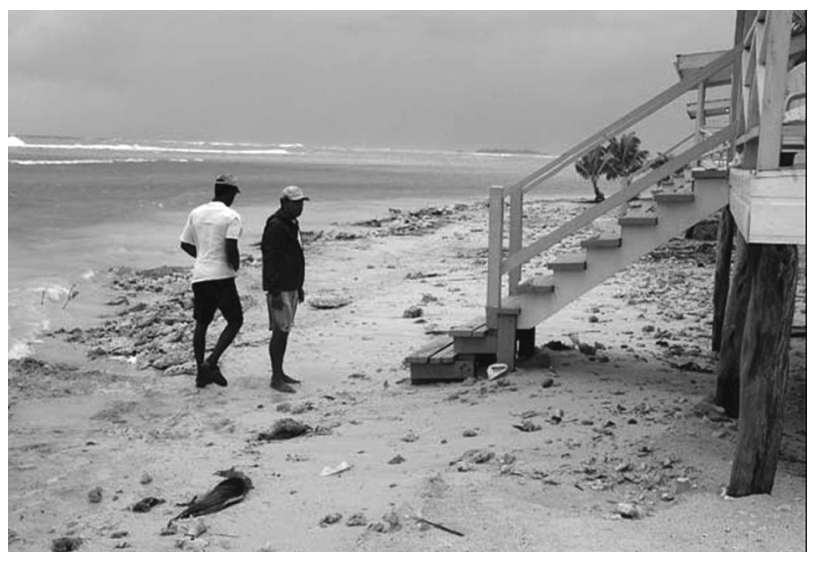

Fig. 4. Effect of a tropical storm on a beach where mangroves have been cleared. The bottom 2 steps were constructed days after 'Wilma' caused extensive sand removal, exposing the previously buried rocks now visible at the water's edge.

Photo: N. Duplaix 
et al. 2005), evidence for the role of mangroves as coastal buffers is increasing as their global coverage declines, and this warrants greater attention in the coastal policy and management arenas.

Acknowledgements. We thank J. Lubchenco, B. Menge, B. Bancroft, M. Brown, M. Hessing-Lewis, J. Howeison, L. Petes, G. Rilov, J. Tyburczy, and J. Compton for comments; V. Henry, K. Purcell, J. Schuening, B. Martin, and B. Ysaguirre for field assistance, and N. Duplaix for additional information and photo use. This work was supported by grants from the National Science Foundation, the National Fish and Wildlife Foundation's Budweiser Conservation Fellowship, and Anchor Environmental.

\section{LITERATURE CITED}

Alongi DM (2002) Present state and future of the world's mangrove forests. Environ Conserv 29:331-349

Avila LA, Pasch RJ, Jing J (2000) Atlantic tropical systems of 1996 and 1997: years of contrasts. Mon Weather Rev 128: 3695-3706

Cahoon DR, Hensel P, Rybczyk J, McKee KL, Proffitt CE, Perez BC (2003) Mass tree mortality leads to mangrove peat collapse at Bay Islands, Honduras after Hurricane Mitch. J Ecol 91:1093-1105

Cesar H (1996) Economic analysis of Indonesian coral reefs. World Bank, New York

Check E (2005) Natural disasters: roots of recovery. Nature 438:910-911

Dahdouh-Guebas R, Jayatissa LP, Di Nitto D, Bosire JO, Lo Seen D, Koedam N (2005) How effective were mangroves as a defence against the recent tsunami? Curr Biol 15: R443-R447

Danielsen F, Sørensen MK, Olwig MF, Selvam V and 8 others (2005) The Asian tsunami: a protective role for coastal vegetation. Science 310:643

Doyle TW, Smith TJ III, Robblee MB (1995) Wind damage effects of Hurricane Andrew on mangrove communities along the southwest coast of Florida, USA. J Coast Res 21: 159-168

Ellison AM (2000) Mangrove restoration: do we know enough? Restor Ecol 8:219-229

Feagin RA, Sherman DJ, Grant WE (2005) Coastal erosion, global sea-level rise, and the loss of sand dune plant habitats. Front Ecol Environ 7:359-364

Field CB, Osborn JG, Hoffmann LL, Polsenberg JF and 6 others (1998) Mangrove biodiversity and ecosystem function. Glob Ecol Biogeogr Lett 7:3-14

Editorial responsibility: Charles Peterson (Contributing Editor), Morehead City, North Carolina, USA
Hale S (2003) The effect of thinning intensity on the belowcanopy light environment in a Sitka spruce plantation. For Ecol Manag 179:341-349

Kar R, Kar RK (2005) Mangroves can check the wrath of tsunami. Current Sci (Bangalore) 88:675

Mazda Y, Magi M, Kogo M, Hong P (1997a) Mangroves as a coastal protection from waves in the Tong King delta, Vietnam. Mangroves Salt Marshes 1:127-135

Mazda Y, Wolanski E, King B, Sase A, Ohtsuka D, Magi M (1997b) Drag force due to vegetation in mangrove swamps. Mangroves Salt Marshes 1:193-199

Mazda Y, Magi M, Nanao H, Kogo M, Miyagi T, Kanazawa N, Kobashi D (2002) Coastal erosion due to long-term human impact on mangrove forests. Wetl Ecol Manag 10:1-9

McCarthy JJ, Canziani OF, Leary NA, Dokken DJ, White KS (2001) Climate change 2001: impacts, adaptation and vulnerability. Contribution of Working Group II to the Third Assessment Report of the Intergovernmental Panel on Climate Change. Cambridge University Press, Cambridge

Moberg F, Folke C (1999) Ecological goods and services of coral reef ecosystems. Ecol Econ 29:215-233

Mumby PJ, Edwards AJ, Arias-Gonzalez JE, Lindeman KC and 8 others (2004) Mangroves enhance the biomass of coral reef fish communities in the Caribbean. Nature 427: $533-536$

Ogden JC, Gladfelter EH (eds) (1983) Coral reefs, seagrass beds and mangroves: their interaction in the coastal zones of the Caribbean. Report of a Workshop held at West Indies Laboratory, St. Croix, US Virgin Islands, May 1982. UNESCO reports in marine science 123. UNESCO, Paris

Pasch RJ, Blake ES, Cobb HD III, Roberts DP (2006) Tropical cyclone report: Hurricane Wilma 15-25 October 2005. NOAA, National Hurricane Center, Miami, FL

Sokal RR, Rohlf FJ (1995) Biometry. WH Freeman, New York

Stewart SR (2005) Tropical cyclone report: Tropical Storm Gamma. Report no. AL272005. NOAA, National Hurricane Center, Miami, FL

Stoddart DR (1963) Effects of Hurricane Hattie on the British Honduras reefs and cays, October 30-31, 1961. Atoll Res Bull 95:1-142

Takashima A, Kume A, Yoshida S (2006) Methods for estimating understory light conditions using crown projection maps and topographic data. Ecol Res 21:560-569

UNEP (United Nations Environment Programme) (1995) Global biodiversity assessment. Cambridge University Press, Cambridge

Wells S, Ravilous C, Corcoran E (2006) In the front line: shoreline protection and other ecosystem services from mangroves and coral reefs. UNEP World Conservation Monitoring Centre, Cambridge, UK

Williams N (2005) Tsunami insight to mangrove value. Current Biol 15:R73

Submitted: January 12, 2007; Accepted: June 4, 2007

Proofs received from author(s): July 27, 2007 